\title{
Nitric Oxide Mediates the Microbicidal Activity of Eosinophils
}

\section{Sandra HP Oliveira, Simone G Fonseca, Pedro RT Romão, Sérgio H Ferreira, Fernando Q Cunha ${ }^{+}$}

\begin{abstract}
Departamentos de Farmacologia e Microbiologia, Parasitologia e Imunologia, Faculdade de Medicina de
\end{abstract} Ribeirão Preto, Universidade de São Paulo, Av. Bandeirantes 900, 14049-900 Ribeirão Preto, SP, Brazil

There are several experimental evidences that nitric oxide $(N O)$ is involved in the microbicidal activity of macrophages against a number of intracellular pathogens including Leishmania major, Trypanozoma cruzi, Toxoplasma gondii. It is also well known that eosinophils (EO) have microbicidal activity against many parasites such as Schistosoma mansoni, Trichinella spiralis, T. cruzi and L. amazonensis. The purpose of this study was to investigate if NO is involved in the microbicidal activity of EO against L. major. Eosinophils harvested from peritoneal cavity of rats released spontaneously after 24 and $48 \mathrm{hr}$ a small amount of nitrite. This release was enhanced by the treatment of cells with IFN- $\gamma(200 \mathrm{IU} / \mathrm{ml})$. This release was blocked by addition of the NO synthase inhibitor, L-NIO (100 $\mu M)$ into the culture. To determinate the leishmanicidal activity of eosinophils the parasites were incubated with activated eosinophils with IFN- $\gamma$ and the ability of surviving parasites to incorporate $\left[{ }^{3} H\right]$ thymidine

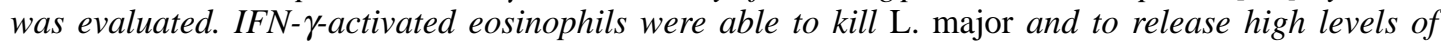
nitrite. The ability to destroy L. major and the release of NO were completely blocked by L-NIO. These results indicate that activated eosinophils release NO which is involved in the microbicidal activity of these cells against $\mathrm{L}$. major.

Key words: nitric oxide - eosinophils - microbicidal activity - Leishmania major

The microbicidal activity of eosinophils has been associated with degranulation and release of granule-protein such as major basic protein (MBP), eosinophil peroxidase (EPO), eosinophil cationic protein (ECP) and eosinophil-derived neurotoxin (EDN). These substances are cytotoxic to cells and to several parasites in vitro (Gleich et al. 1992), among them, Trichinella spiralis (Wassom \& Gleich 1979), Onchocerca volvulus (Greene et al. 1981), Toxocara canis (Badley et al. 1987), Fasciola hepatica (Duffus et al. 1980), Necator americanus (Desakorn et al. 1987), Nippostrongylus brasiliensis (Kojima et al. 1985), Schistosoma mansoni (Capron et al. 1979, Butterworth et al. 1979), Trypanosoma cruzi (Villalta \& Kierszenbaum 1984), Plasmodium falciparum (Waters et al. 1987), Leishmania mexicana amazonensis (Pimenta et al. 1987) and L. donovani (Pearson et al. 1987). In addition to the granule proteins, oxygen-free radicals, including the toxic singlet oxygen, seem to contribute to the microbicidal activity of eosinophils (Pincus et al. 1984).

${ }^{+}$Corresponding author. Fax: +55-16-633.2301. E-mail: fdqcunha@fmrp.usp.br

Received 3 September 1997

Accepted 30 September 1997
Nitric oxide (NO) or nitrogen-derived metabolites have been identified as major effector molecules involved in the macrophage microbicidal activity against most intracellular pathogens, including L. major (Liew \& Millott 1990), Toxoplasma gondii (Adams et al. 1990), T. musculi (Vincendeau \& Dalouede 1991), T. cruzi (Gazzinelli et al. 1992), P. berghei (Mellouk et al. 1991), Mycobacterium leprae (Adams et al. 1991), M. avium (Denis 1991), Candida albicans (Cenci et al. 1993) and the virus Ectromelia, vaccinia and herpes simplex-1 (Gunasegaran et al. 1993). Recently, it was demonstrated that the microbicidal activity of neutrophils against C. albicans is also mediated by NO (Fierro et al. 1996).

Since at present there is no experimental demonstration of the contribution of nitric oxide to the microbicidal activity of eosinophils, the aim of this study was to investigate whether eosinophils produce nitric oxide and whether NO is involved in the microbicidal activity of these cells against $L$. major.

To investigate if eosinophils are able to produce nitric oxide, these cells were harvested from peritoneal cavities of rats and incubated in vitro with IFN- $\gamma$. Eosinophils released spontaneously a small amount of nitrite when incubated in vitro. Levels of nitrite in the medium were already present after $12 \mathrm{hr}$ of incubation, which increased continu- 
ously within $48 \mathrm{hr}$. The stimulation of eosinophils with $\mathrm{mIFN}-\gamma$ enhanced the release of the nitrite after 24 and $48 \mathrm{hr}$ of incubation. A similar effect of IFN- $\gamma$ has been described in macrophages (Liew \& Millott, 1990, Cunha et al. 1993). Nitrite production by the stimulated eosinophils was abolished by the NO synthase inhibitor L-NIO (McCall et al. 1992), indicating that the nitrite measured by the Griess method resulted from the oxidation of L-arginine by NO synthase (Fig. 1).

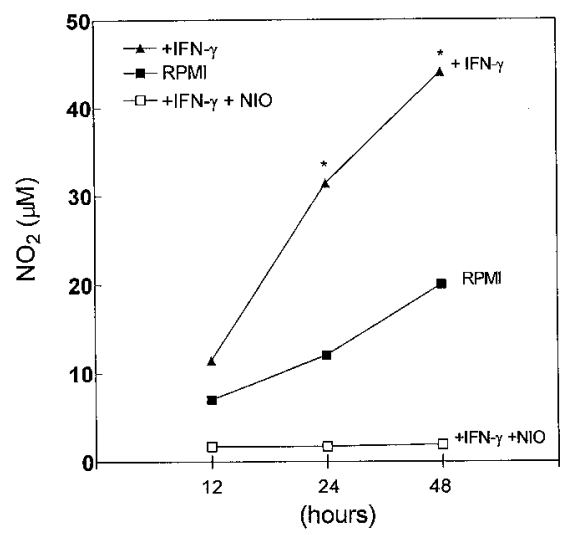

Fig. 1: level of nitrite in the culture supernatants of eosinophils incubated with RPMI, mIFN- $\gamma(200 \mathrm{IU} / \mathrm{ml})$ in the presence or absence of L-NIO $(100 \mu \mathrm{M})$. The nitrite concentration was determined at $12 \mathrm{hr}, 24 \mathrm{hr}$ and $48 \mathrm{hr}$ after eosinophils stimulation by the Griess methods. Data are reported as means \pm SEM of assays performed in triplicate and are representative of two different experiments. * p $<0.05$ compared to RPMI (ANOVA followed by Bonferroni t-test).

An important protective role for reactive nitrogen intermediates has been established in macrophage killing of intracellular protozoa (Liew \& Millott 1990, Adams et al. 1990, Vincendeau \& Dalouede 1991, Gazzinelli et al. 1992), bacteria (Adams et al. 1991, Denis 1991), fungus (Cenci et al. 1993) and virus (Gunasegaran et al. 1993). A similar role has also been demonstrated in neutrophil killing of C. albicans (Fierro et al. 1996) and Staphilococcus aureus (Malawista et al. 1992). Since there are data showing that eosinophils are able to kill Leishmania (Pimenta et al. 1987, Pearson et al. 1987), we investigated whether NO mediates the killing of this intracellular parasite by stimulated eosinophils. IFN- $\gamma$-activated eosinophils were able to kill $L$. major and to release high levels of nitrite. The ability to destroy L. major and the release of $\mathrm{NO}$ were completely blocked by L-NIO, suggesting that NO mediate the leishmanicidal activity of eosinophils. Leishmania survival inside the unstimulated eosinophils was not affect by L-NIO treatment (Fig. 2). These results, together with the findings that eosinophils are present in Leishmania lesions (Katakura et al. 1993), reinforce the importance to investigate the role of eosinophils in the evolution of leishmaniasis.

Thus, the data obtained in the present study indicate that activated eosinophils release NO which may be involved in the microbicidal activity of these cells against $L$. major.

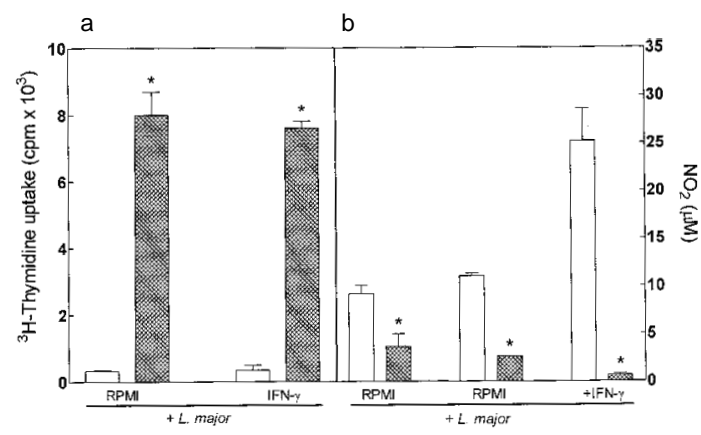

Fig. 2: killing of Leishmania major by eosinophils incubated with RPMI, or stimulated with $\mathrm{mIFN}-\gamma(200 \mathrm{IU} / \mathrm{ml})$ in the presence or absence of L-NIO (100 $\mu \mathrm{M})$ (panel a). Panel b: level of nitrite in the supernatant of eosinophils incubated with $L$. $m a$ jor and stimulated with IFN- $\gamma(200 \mathrm{IU} / \mathrm{ml})$. Leishmanicidal activity is reported as the ability of residual parasites to incorporate $\left[{ }^{3} \mathrm{H}\right]$ thymidine. Data are presented as means \pm SEM of assays performed in triplicate and are representative of three different experiments. * $\mathrm{p}<0.05$ compared to RPMI (ANOVA followed by Bonferroni $t$-test).

\section{REFERENCES}

Adams B, Hibbs JB, Taintor RR, Krahenbuhl JL 1990. Microbiostatic effect of murine activated macrophages for Toxoplasma gondii. Role for synthesis of inorganic nitrogen oxides from L-arginine. $J$ Immunol 144: 2725-2729.

Adams LB, Franzblau SG, Vavrin V, Hibbs JRJ, Krahenbuhl JL 1991. L-arginine-dependent macrophage effector functions inhibit metabolic activity of Mycobacterium leprae. J Immunol 147: 1642 1646.

Badley JE, Grieve RB, Rockey JH, Glickman LT 1987. Immune mediated adherence of eosinophils to Toxocara canis infective larvae: the role of excretorysecretory antigens. Parasite Immunol 9: 133-143.

Butterworth AE, Wassom DL, Gleich GJ, Loegering DA, David JR 1979. Damage to schistosomula of Schistosoma mansoni induced directly by eosinophil major basic protein. J Immunol 122: 221-229.

Capron M, Torpier G, Capron A 1979. In vitro killing of $S$. mansoni schistosomulo by eosinophils from infected rats: role of cytophilic antibodies. J Immunol 123: 2220-2230.

Cenci E, Romani L, Mencacci A, Spaccapelo R, Schiabbella E, Paccetti P, Bistoni F 1993. Interleukin4 and interleukin-10 inhibit nitric oxide-dependent macrophage killing of Candida albicans. Eur $J$ Immunol 23: 1034-1038. 
Cunha FQ, Moss DK, Leal LMCC, Moncada S, Liew FY 1993. Induction of macrophages parasiticidal activity by Staphylococcus aureus and exotoxins through the nitric oxide synthasis pathways. Immunology 78: 563-567.

Denis M 1991. Tumor necrosis factor and granulocytes macrophages-colony stimulating factor stimulate human macrophages to restrict growth of virulent Mycobacterium avium and to kill avirulent $M$. avium: Killing effector mechanism depends on the generation of reactive nitrogen intermediates. J Leuk Biol 49: 380-387.

Desakorn V, Suntharasamai P, Pukrittayakamee S, Migasena S, Bunnag D 1987. Adherence of human eosinophils to infective filariform larvae of Necator americanus in vitro, Southeast Asian. J Trop Med Pub Health 18: 66-72.

Duffus WP, Thorne K, Oliver R 1980. Killing of juvenile Fasciola hepatica by purified bovine eosinophil proteins. Clin Exp Immunol 40: 336-340.

Fierro IM, Barja-Fidalgo C, Cunha FQ, Ferreira SH 1996. The involvement of nitric oxide in the anti-Candida albicans activity of rat neutrophils. Immunology 89 : 295-300.

Gazzinelli RT, Oswald IP, Heiny S, James SL, Sher A 1992. The microbicidal activity of interferon treated macrophages against Trypanosoma cruzi involves an L-arginine-dependent, nitrogen oxide-mediated mechanism inhibitable by interleukin-10 and transforming growth factor- $\beta$. Eur J Immunol 22: 25012506.

Gleich GJ, Adolphson CR, Leiferman KM 1992. Eosinophils, p. 663. In JI Galli, IM Goldestein, R Snyderman (eds). Inflammation: Basic Principles and Clinical Correlates, $2^{\text {nd }}$ ed., Raven Press, New York.

Greene BM, Taylor HR, Aikawa M 1981. Cellular killing of microfilariae of Onchocerca volvulus: eosinophil and neutrophil-mediated immune serum-dependent destruction. J Immunol 127: 1611-1618.

Gunasegaran K, Xie Q-W, Buller RM, Nathan C, Duarte C, MacMicking JD 1993. Inhibition of viral replication by interferon- $\gamma$-induced nitric oxide synthase. Science 261: 1445-1447.

Katakura K, Saito S, Hamada A, Matsuda H, Watanabe N 1993. Cutaneous leishmaniasis in mast cell-deficient W/Wv mice. Infect Immunity 61: 2242-2244.

Kojima S, Yamamoto N, Kanazawa T, Ovary Z 1985. Monoclonal IgE-dependent eosinophil cytotoxicity to haptenated schistosomula of Schistosoma japonicum: enhancement of the cytotoxixity and expression of $\mathrm{Fc}$ receptors for $\mathrm{IgE}$ by Nippostrongylus brasiliensis infection. J Immunol 34: 2719-2722.
Liew FY, Li Y, Millott S 1990. Tumor necrosis factor- $\alpha$ synergizes with IFN- $\gamma$ in mediating killing of Leishmania major through the induction of nitric oxide. $J$ Immunol 145: 4306-4310.

Malawista SE, Montgomery RR, Van Blaricom G 1992. Evidence for reactive nitrogen intermediates in killing of Staphylococci by human neutrophil cytoplasts. A new microbicidal pathway for polymorphonuclear leukocytes. J Clin Invest 90: 631-636.

McCall TB, Palmer RMJ, Moncada S 1992. Induction of nitric oxide synthase in rat peritoneal neutrophils and its inhibition by dexamethasone and the cytokine interleukin-8, p. 140. In S Moncada, MA Marletta, JB Hibbs Jr, EA Higgs (eds). The Biology of Nitric Oxide: 2 Enzymology, Biochemistry and Immunology, Vol 1, Portland Press, London.

Mellouk S, Green SJ, Nacy CA, Hoffman SL 1991. IFN$\gamma$ inhibit development of Plasmodium berghei exoerythrocytic stages in hepathocytes by an L-arginine-dependent effector mechanism. J Immunol 146: 3971-3976

Pearson RD, Uydess IL, Chapman SW, Steigbigel RT 1987. Interaction of human eosinophils with Leishmania donovani. Ann Trop Med Parasitol 81: 735739.

Pimenta PFP, Dos Santos MAV, De Souza W 1987. Fine structure and cytochemistry of the interaction between Leishmania mexicana amazonensis and rat neutrophils and eosinophils. J Submicrosc Cytol 19: 387-395.

Pincus SH, Butterworth AE, David JR, Robbins M, Vadas MA 1984. Eosinophil-mediated killing of Schistosoma mansoni: oxidative requirement for enhancement by eosinophil colony stimulating factor (CSF $\alpha$ ) and supernatants with eosinophil cytotoxicity enhancing activity (ECEA). Cell Immunol 87: 424-433.

Villalta F, Kierszenbaum F 1984. Role of inflammatory cells in Chagas' disease. I. Uptake and mechanism of destruction of intracellular (amastigote) forms of Trypanosoma cruzi by human eosinophils. $J$ Immunol 132: 2053-2058.

Vincendeau P, Dalouede S 1991. Macrophages cytostatic effect on Trypanosoma musculi involves an L-arginine-dependent mechanism. J Immunol 146: 43384343.

Wassom DL, Gleich GJ 1979. Damage to Trichinella spiralis newborn larvae by eosinophil major basic protein. Am J Trop Med Hyg 28: 860-863.

Waters LS, Taverne J, Tai PC, Spry CJ, Targett GA, Playfair JH 1987. Killing of Plamodium falciparum by eosinophil secretory products. Infect Immunity 55: $877-881$. 